\title{
PENINGKATAN KEMAMPUAN ANAK MENGUCAPKAN SUKU KATA DENGAN MENGGUNAKAN STRATEGI KONTEKSTUAL
}

\author{
Sunarwati \\ Afifjos773@gmail.com \\ Kepala TK Bunga Harapan Kec.Babat
}

\begin{abstract}
ABSTRAK
Sebagai bagian dari rangkaian kegiatan upaya untuk mengetahui dan meningkatkan perkembangan pendidikan taman kanak kanak, maka salah satu bidang pengetahuan terapan yang diharapkan semakin memberi sumbangan bagi perkembangan pendidikan di tanah air ialah bidang teknologi pendidikan. Kemampuan untuk memanfaat teknologi modern dalam upaya pengembangan pendidikan tertentu saja sangat tergantung pada jumlah dan kemampuan para ahli dalam bidang teknologi pendidikan. Proses belajar mengajar pada hakikatnya adalah proses komunikasi, yaitu proses penyampaian pesan dari sumber pesan melalui saluran media tertentu ke penerima pesan. Pesan, sumber pesan, saluran / media dan penerima pesan adalah komponen - komponen proses komunikasi. Pesan yang akan dikomunikasikan adalah isi ajaran atau didikan yang ada dalam kurikulum. Sumber pesannya bisa guru, anak, orang lain, ataupun penulis buku dan produser media. Salurannya ialah media pendidikan dan penerima pesannya ialah para anak atau peserta didik atau juga guru. Tujuan dari penelitian tindakan kelas ( PTK ) ini adalah untuk mengetahui sejauh mana penerapan strategi kontekstual dapat meningkatkan kemampuan anak dalam mengucapkan suku kata. Dalam penelitian tindakan kelas ( PTK ) ini dilakukan dalam 3 siklus, dari hasil tindakan yang dilakukan terbukti dapat meningkatkan kemampuan anak dalam mengucapkan suku kata dengan mencapai standar ideal $67.92 \%$ pada siklus I, dapat meningkat menjadi $71.83 \%$ pada siklus II, dan siklus ke III $78.33 \%$. Hasil penelitian tindakan ini menunjukkan pembelajaran dengan menggunakan strategi kontekstual efektif dalam meningkatkan kemampuan anak dalam mengucapkan suku kata di TK Bunga Harapan Kec. Babat dengan ketuntasan mencapai 91.67\%.
\end{abstract}

Kata Kunci: Teori Kemampuan Membaca, Strategi Pembelajaran Kontekstual.

\section{PENDAHULUAN}

Ilmu pengetahuan dan teknologi pada saat ini mengalami kemajuan yang sangat pesat dan hal tersebut sangat mempengaruhi perkembangan pendidikan terutama di tingkat dasar, khususnya di taman kanak kanak. Disadari bahwa pendidikan di taman kanak - kanak tentunya memerlukan perhatian khusus yang disesuaikan dengan perkembangan dan kemajuan ilmu pengetahuan dan teknologi ( IPTEK ). Oleh karena itu sistem pendidikan pun harus mampu mengimbangi perkembangan dari IPTEK tersebut. Telah banyak upaya yang dilakukan pemerintah dan pakar pendidikan dalam menciptakan suatu kondisi belajar yang menggugah rasa kebermaknaan bagi peserta didik, berbagai pendekatan, metode, strategi maupun isi dari pembelajaran itu sendiri, telah banyak mengalami perkembangan sesuai dengan tuntutan zaman baik itu di tingkat TK, SD,
SMP, SMA bahkan perguruan tinggi, yang tak lain bertujuan untuk meningkatkan dan memajukan bidang pendidikan, khususnya pendidikan pada tingkat taman kanak kanak ( TK ).

Sebagai bagian dari rangkaian kegiatan upaya untuk mengetahui dan meningkatkan perkembangan pendidikan taman kanak kanak, maka salah satu bidang pengetahuan terapan yang diharapkan semakin memberi sumbangan bagi perkembangan pendidikan di tanah air ialah bidang teknologi pendidikan. Kemampuan untuk memanfaat teknologi modern dalam upaya pengembangan pendidikan tertentu saja sangat tergantung pada jumlah dan kemampuan para ahli dalam bidang teknologi pendidikan.

Jika kita bergerak dalam bidang pendidikan dan latihan, baik sebagai guru, dosen, pelatih, instruktur, pengelola atau bahkan sebagai anak, mahasiswa dan 
pihak yang dilatih, barang kali istilah proses belajar mengajar tidak asing lagi. Istilah lain sering dipakai adalah kegiatan belajar mengajar. Dalam kedua istilah tersebut kita melihat adanya dua proses atau kegiatan, yaitu : proses / kegiatan belajar dan proses / kegiatan mengajar. Kedua prses tersebut seolah-olah terpisahkan satu sama lain. Orang menganggap bahwa ada proses belajar tentu ada proses mengajar. Seseorang belajar karena ada yang mengajar. Tapi benarkah itu ? Kalau kita mengajar kita pandang sebagai kegiatan atau proses yang terarah dan terencana yang mengusahakan agar terjadi proses belajar pada diri seseorang, pendapat tersebut tidaklah benar. Proses belajar mengajar dapat terjadi kapan saja dan di mana saja terlepas dari ada yang mengajar atau tidak. Proses belajar terjadi karena adanya interaksi individu dengan lingkungannya.

Proses belajar mengajar pada hakikatnya adalah proses komunikasi, yaitu proses penyampaian pesan dari sumber pesan melalui saluran media tertentu ke penerima pesan. Pesan, sumber pesan, saluran / media dan penerima pesan adalah komponen - komponen proses komunikasi. Pesan yang akan dikomunikasikan adalah isi ajaran atau didikan yang ada dalam kurikulum. Sumber pesannya bisa guru, anak , orang lain, ataupun penulis buku dan produser media. Salurannya ialah media pendidikan dan penerima pesannya ialah para anak atau peserta didik atau juga guru.

Kita tentu mengenal adanya hambatan belajar yang disebabkan oleh faktor psikologis, seperti minat, sikap, pendapat, kepercayaan, inteligensi pengetahuan, dan hambatan fisik seperti kelelahan, sakit, keterbatasan daya indra dan cacat tubuh. Anak yang senang terhadap mata pelajaran tertentu topik serta gurunya, tentu lain hasil belajarnya dibandingkan dengan mata pelajaran yang ia benci atau yang ia tidak sukai. Dua jenis hambatan yang lain adalah hambatan kultural seperti perbedaan adat sitiadat, norma - norma sosial, kepercayaan dan nilai - nilai panutan, dan hambatan lingkungan yaitu hambatan yang ditimbulkan situasi dan kondisi keadaan sekitar. Proses belajar mengajar di tempat yang tenang, sejuk dan nyaman tentu akan berbeda dengan proses yang dilakukan di kelas yang bising, panas, dan berjubel. Perbedaan adat istiadat, norma sosial dan kepercayaan kadang - kadang bisa menjadi sumber salah paham. Media pendidikan sebagai salah satu sumber belajar yang dapat menyalurkan pesan sehingga membantu mengatasi hal tersebut. Perbedaan gaya belajar, minat, inteligensi, keterbatasan gaya indera, cacat tubuh atau hambatan jarak geografis, jarak waktu dan lain - lain dapat dibantu diatasi dengan pemanfaatan media pendidikan.

Salah satu media yang dapat digunakan dalam proses belajar mengajar di taman kanak kanak adalah dengan menggunakan Strategi Kontekstual dalam melaksanakan bimbingan sebagai upaya meningkatkan kemampuan anak dalam mengucapkan suku kata pelajaran bahasa Indonesia. Strategi Kontekstual adalah salah satu mengajar yang dilakukan oleh guru dengan lebih banyak memberikan latihan-latihan soal yang bertujuan antara lain untuk memperoleh kecakapan mental, melatih anak agar lebih cermat dan tepat dalam mengerjakan soal dan agar anak memiliki ketangkasan atau ketrampilan yang lebih tinggi.

Sehubungan dengan hal di atas, maka penulis perlu melakukan penelitian tindakan untuk mengetahui kemampuan anak melalui suatu penelitian tindakan dengan judul : "Peningkatan Kemampuan Anak Mengucapkan Suku Kata Dengan Menggunakan Strategi Kontekstual Kelompok B di TK BUNGa HARAPAN KEC. BABAT Tahun Pelajaran 2018-2019“. Adapun tujuan utama dari penelitian ini adalah (1) untuk mengetahui peningkatan kemampuan anak mengucapkan suku kata dengan menggunakan strategi kontekstual kelompok B di TK Bunga Harapan Kec. Babat tahun pelajaran 2018-2019. (2) untuk 
mengetahui Efektivitas strategi kontekstual meningkatkan kemampuan anak mengucapkan suku kata dengan menggunakan kelompok B di TK Bunga Harapan Kec. Babat tahun pelajaran 20182019.

\section{METODE}

Subjek penelitian ini adalah meningkatkan kemampuan anak dalam mengucapkan suku kata yang dilaksanakan di TK Bunga Harapan Kec. Babat. Berdasarkan hasil observasi yang penulis lakukan bahwa kelompok B TK Bunga Harapan Kec. Babat prestasi belajarnya masih sangat rendah. Anak merasa kesulitan dalam belajar sehingga anak kurang respon terhadap pembelajaran di kelas. Penelitian ini merupakan penelitian tindakan kelas, yang dilakukan secara bertahap-tahap sampai mendapatkan hasil yang diinginkan. Tindakan dilaksanakan dalam 3 siklus. Dalam pelaksanaan tindakan, rancangan dilakukan dalam 3 siklus yang meliputi ; (a) perencanaan, (2) tindakan, (3) pengamatan, (4) refleksi.

Dalam penelitian tindakan kelas ini variabel yang diteliti adalah peningkatan kemampuan anak mengucapkan suku kata dengan menggunakan strategi kontekstual kelompok B di TK Bunga Harapan Kec. Babat tahun pelajaran 2018-2019. Variabel tersebut dapat dituliskan kembali sebagai berikut: (1) Variabel harapan: Kemampuan mengucapkan suku kata. (2) Variabel tindakan: Pembelajaran dengan menggunakan strategi kontekstual. Sumber data dalam penelitian ini berasal dari dua sumber yaitu: (1) Anak: Diperoleh data tentang kemampuan anak mengucapkan suku kata. (2) Guru: Diperoleh data tentang penerapan pembelajaran dengan menggunakan strategi kontekstual. Dalam pengumpulan data teknik yang digunakan adalah menggunakan observasi , dan data dari guru TK, dokumentasi.

Penelitian tindakan kelas yang dilaksanakan dalam tiga siklus dianggap sudah berhasil apabila terjadi peningkatan kemampuan anak dalam menucapkan suku kata apabila $85 \%$ anak ( kelas yang diteliti ) telah mencapai ketuntasan anak sudah bisa mengungkapkan suku kata. Jika peningkatan tersebut dapat dicapai pada tahap siklus 1 dan 2, maka siklus selanjutnya tidak dilaksanakan karena tindakan kelas yang dilakukan sudah dinilai efektif sesuai dengan harapan dalam kurikulum tingkat satuan pendidikan ( KTSP ).

\section{HASIL DAN PEMBAHASAN}

\section{Perencanaan Tindakan}

Penelitian ini menggunakan pembelajaran melalui penerapan strategi kontekstual. Tujuan yang diharapkan pada pertemuan pertama dalam pembelajaran di TK Bunga Harapan Kec. Babat adalah meningkatkan kemampuan anak mengucapkan suku kata. Agar tercapai tujuan di atas, peneliti yang bertindak sebagai guru melakukan langkah-langkah sebagai berikut : (a) Menyusun instrumen pembelajaran. (b) Menyusun Instrumen Monitoring, (c) Sosialisasi kepada anak, (d) Melaksanakan tindakan dalam pembelajaran, (e) Melakukan refleksi, (f) Menyusun strategi pembelajaran pada siklus ke dua berdasar refleksi siklus pertama, (g) Melaksanakan pembelajaran pada siklus kedua, (h) Melakukan Observasi, (i) Melakukan refleksi pada siklus kedua, (j) Menyusun strategi pembelajaran pada siklus ketiga berdasar refleksi siklus kedua, (k) Melaksanakan pembelajaran pada siklus ketiga, (l) Melakukan Observasi, (m) Melakukan refleksi pada siklus ketiga, dan (n) Menyusun laporan

\section{Pelaksanaan Tindakan dan Pengamatan}

Pelaksanaan tindakan dalam penelitian dilakukan 3 siklus yang terdiri dari enam kali pertemuan. Waktu yang digunakan setiap kali pertemuan adalah $2 \mathrm{x}$ 30 menit. Pertemuan pertama dilaksanakan pada tanggal 10 s.d 17 September 2018 dan pertemuan kedua pada tanggal 24 September 2018 s.d 07 Oktober 2018, dan 
pertemuan ke tiga 15 s.d 22 Oktober 2018. Penelitian tindakan kelas dilaksanakan sesuai dengan prosedur rencana pembelajaran dan skenario pembelajaran.

\section{SIKLUS 1}

a) Tahap Perencanaan

Pada tahap ini peneliti mempersiapkan perangkat pembelajaran yang terdiri dari rencana pelajaran 1, LKS 1 , soal tes formatif 1 dan alat-alat pengajaran yang mendukung. Selain itu juga dipersiapkan lembar observasi pengolaan pembelajaran.

b) Tahap Kegiatan dan Pelaksanaan

Pelaksanaan kegiatan belajar mengajar untuk siklus I dilaksanakan pada tanggal 10 s.d 17 September 2018 di TK Bunga Harapan Kec. Babat tahun Pelajaran 2018-2019 dengan jumlah anak 12 orang. Dalam hal ini peneliti bertindak sebagai guru. Adapun proses belajar mengajar mengacu pada rencana pelajaran yang telah dipersiapkan. Pengamatan (observasi) dilaksanakan bersamaan dengan pelaksaaan belajar mengajar. Pada akhir proses belajar mengajar anak diberi tes formatif I dengan tujuan untuk mengetahui tingkat keberhasilan anak dalam proses belajar mengajar yang telah dilakukan. Adapun data hasil penelitian pada siklus I. adalah seperti pada tabel berikut:

Tabel 1. Distribusi Nilai Tes Peningkatan Kemampuan Anak Mengucapkan Suku Kata Pada Siklus I

\begin{tabular}{|c|c|c|c|c|}
\hline \multirow[b]{2}{*}{ No } & \multirow[b]{2}{*}{ Nama Anak } & \multirow[b]{2}{*}{ Skor } & \multicolumn{2}{|c|}{ Keterangan } \\
\hline & & & Tuntas & Tidak Tuntas \\
\hline 1 & Alfi & 65 & & $\sqrt{ }$ \\
\hline 2 & Balqis & 65 & & $\sqrt{ }$ \\
\hline 3 & Bintang & 65 & & $\sqrt{ }$ \\
\hline 4 & Candra & 65 & & $\sqrt{ }$ \\
\hline 5 & Rissa & 65 & & $\sqrt{ }$ \\
\hline 6 & Faiza & 60 & & $\sqrt{ }$ \\
\hline 7 & Nayla & 60 & & $\sqrt{ }$ \\
\hline 8 & Friska & 75 & $\sqrt{ }$ & \\
\hline 9 & Obi & 75 & $\sqrt{ }$ & \\
\hline 10 & Najwa & 70 & & $\sqrt{ }$ \\
\hline 11 & Alfis & 75 & $\sqrt{ }$ & \\
\hline 12 & Robbi & 75 & $\sqrt{ }$ & \\
\hline \multicolumn{2}{|c|}{ Jumlah Total } & 815 & - & - \\
\hline \multicolumn{2}{|c|}{ Skor Maksimum Individu } & 100 & - & - \\
\hline \multicolumn{2}{|c|}{ Skor Maksimum Kelas } & 1200 & - & - \\
\hline
\end{tabular}

c) Refleksi

Dari tabel di atas dapat dijelaskan

Dalam pelaksanaan kegiatan belajar bahwa dengan menerapkan strategi kontekstual diperoleh nilai rata-rata prestasi belajar anak adalah78.33\% atau ada 4 anak dari 12 anak sudah tuntas belajar. Hasil tersebut menunjukkan bahwa pada siklus pertama secara klasikal anak belum tuntas belajar, karena anak yang memperoleh nilai $\geq 75$ hanya sebesar 33.33 $\%$ lebih kecil dari persentase ketuntasan yang dikehendaki yaitu sebesar $85 \%$. Hal ini disebabkan karena anak masih merasa baru dan belum mengerti apa yang dimaksudkan dan digunakan guru dengan menerapkan strategi kontekstual. mengajar diperoleh informasi dari hasil pengamatan sebagai berikut: (1) Guru kurang baik dalam memotivasi anak dan dalam menyampaikan tujuan pembelajaran, (2) Guru kurang baik dalam pengelolaan waktu, (3) Anak kurang begitu antusias selama pembelajaran berlangsung.

d) Revisi Rancangan

Pelaksanaan kegiatan belajar mengajar pada siklus I ini masih terdapat kekurangan, sehingga perlu adanya revisi untuk dilakukan pada siklus berikutnya. (1) Guru perlu lebih terampil dalam memotivasi anak dan lebih jelas dalam 
menyampaikan tujuan pembelajaran. Di mana anak diajak untuk terlibat langsung dalam setiap kegiatan yang akan dilakukan. (2) Guru perlu mendistribusikan waktu secara baik dengan menambahkan informasi-informasi yang dirasa perlu dan memberi catatan. (3) Guru harus lebih terampil dan bersemangat dalam memotivasi anak sehingga anak bisa lebih antusias.

\section{SIKLUS II}

a) Tahap perencanaan

Pada tahap ini peneliti mempersiapkan perangkat pembelajaran yang terdiri dari rencana pelajaran 2 , soal tes formatif II dan alat-alat pengajaran yang mendukung.

b) Tahap kegiatan dan pelaksanaan

Pelaksanaan kegiatan belajar

mengajar untuk siklus II dilaksanakan pada tanggal 24 September 2018 s.d 07 Oktober 2018 di TK Bunga Harapan Kec. Babat tahun pelajaran 2018-2019. Dalam hal ini peneliti bertindak sebagai guru. Adapun proses belajar mengajar mengacu pada rencana pelajaran dengan memperhatikan revisi pada siklus I, sehingga kesalahan atau kekurangan pada siklus I tidak terulang lagi pada siklus II. Pengamatan (observasi) dilaksanakan bersamaan dengan pelaksanaan belajar mengajar. Pada akhir proses belajar mengajar anak diberi tes formatif II dengan tujuan untuk mengetahui tingkat keberhasilan anak dalam proses belajar mengajar yang telah dilakukan. Instrumen yang digunakan adalah tes formatif II. Adapun data hasil penelitian pada siklus II adalah sebagai berikut;

Tabel 2. Distribusi Nilai Tes Peningkatan Kemampuan Anak Mengucapkan Suku Kata Pada Siklus II Keterangan

\begin{tabular}{|c|c|c|c|c|}
\hline No & Nama Anak & Skor & Tuntas & $\begin{array}{l}\text { Tidak } \\
\text { Tuntas }\end{array}$ \\
\hline 1 & Alfi & 75 & $\sqrt{ }$ & \\
\hline 2 & Balqis & 75 & $\sqrt{ }$ & \\
\hline 3 & Bintang & 70 & & $\sqrt{ }$ \\
\hline 4 & Candra & 75 & $\sqrt{ }$ & \\
\hline 5 & Rissa & 75 & $\sqrt{ }$ & \\
\hline 6 & Faiza & 6 & & $\sqrt{ }$ \\
\hline 7 & Nayla & 65 & & $\sqrt{ }$ \\
\hline 8 & Friska & 75 & $\sqrt{ }$ & \\
\hline 9 & Obi & 75 & $\sqrt{ }$ & \\
\hline 10 & Najwa & 62 & & $\sqrt{ }$ \\
\hline 11 & Alfis & 75 & $\sqrt{ }$ & \\
\hline 12 & Robbi & 75 & $\sqrt{ }$ & \\
\hline Jum & h Total & 862 & & - \\
\hline Sko & Maksimum Individu & 100 & - & - \\
\hline Sko & Maksimum Kelas & 1200 & - & - \\
\hline
\end{tabular}

Dari tabel di atas diperoleh nilai ratarata peningkatan kemampuan anak mengucapkan suku kata adalah $71.83 \%$ dan ketuntasan belajar mencapai $66.67 \%$ atau ada 8 anak dari 12 anak sudah tuntas belajar. Hasil ini menunjukkan bahwa pada siklus II ini ketuntasan belajar secara klasikal telah mengalami peningkatan sedikit lebih baik dari siklus I. Adanya peningkatan hasil belajar anak ini karena setelah guru menginformasikan bahwa setiap akhir pelajaran akan selalu diadakan tes sehingga pada pertemuan berikutnya anak lebih termotivasi untuk belajar. Selain itu anak juga sudah mulai mengerti apa yang dimaksudkan dan dinginkan guru dengan menerapkan strategi kontekstual.

c) Refleksi

Dalam pelaksanaan kegiatan belajar diperoleh informasi dari hasil pengamatan sebagai berikut: (1) Memotivasi anak, (2) Membimbing anak merumuskan 
kesimpulan/menemukan konsep, dan (3) Pengelolaan waktu

d) Revisi Pelaksanaaan

Pelaksanaan kegiatan belajar pada siklus II ini masih terdapat kekurangankekurangan. Maka perlu adanya revisi untuk dilaksanakan pada siklus III antara lain: (1) Guru dalam memotivasi anak hendaknya dapat membuat anak lebih termotivasi selama proses belajar mengajar berlangsung. (2) Guru harus lebih dekat dengan anak sehingga tidak ada perasaan takut dalam diri anak baik untuk mengemukakan pendapat atau bertanya. (3) Guru harus lebih sabar dalam membimbing anak merumuskan kesimpulan/menemukan konsep. (4) Guru harus mendistribusikan waktu secara baik sehingga kegiatan pembelajaran dapat berjalan sesuai dengan yang diharapkan. (5) Guru sebaiknya menambah lebih banyak contoh alat permainan dan memberi soal-soal latihan pada anak untuk dikerjakan pada setiap kegiatan belajar mengajar.

\section{SIKLUS III}

a) Tahap Perencanaan
Pada tahap ini peneliti mempersiapkan perangkat pembelajaran yang terdiri dari rencana pelajaran 3 , soal tes formatif 3 dan alat-alat pengajaran yang mendukung.

b) Tahap kegiatan dan pengamatan

Pelaksanaan kegiatan belajar mengajar untuk siklus III dilaksanakan pada tanggal 15 s.d 22 Oktober 2018 di TK Bunga Harapan Kec. Babat tahun Pelajaran 2018-2019 dengan jumlah anak 12 anak. Dalam hal ini peneliti bertindak sebagai guru. Adapun proses belajar mengajar mengacu pada rencana pelajaran dengan memperhatikan revisi pada siklus II, sehingga kesalahan atau kekurangan pada siklus II tidak terulang lagi pada siklus III. Pengamatan (observasi) dilaksanakan bersamaan dengan pelaksanaan belajar mengajar. Pada akhir proses belajar mengajar anak diberi tes formatif III dengan tujuan untuk mengetahui tingkat keberhasilan anak dalam proses belajar mengajar yang telah dilakukan. Instrumen yang digunakan adalah tes formatif III. Adapun data hasil penelitian pada siklus III adalah sebagai berikut:

Tabel 3. Distribusi Nilai Tes Peningkatan Kemampuan Anak Dalam Menucapkan Suku Kata Pada Siklus III

\begin{tabular}{clcr}
\hline & & & Ke \\
No & Nama Anak & Skor & Tu \\
& & & \\
1 & Alfi & 75 \\
2 & Balqis & 75 \\
3 & Bintang & 75 \\
4 & Candra & 75 \\
5 & Rissa & 75 \\
6 & Faiza & 70 \\
7 & Nayla & 80 \\
8 & Friska & 85 \\
9 & Obi & 85 \\
10 & Najwa & 75 \\
11 & Alfis & 85 \\
12 & Robbi & 85 \\
Jumlah Total & $\mathbf{9 4 0}$ \\
Skor Maksimum Individu & $\mathbf{1 0 0}$ \\
Skor Maksimum Kelas & $\mathbf{1 2 0 0}$ \\
\hline \multicolumn{2}{l}{}
\end{tabular}

Berdasarkan tabel di atas diperoleh nilai rata-rata tes formatif sebesar $78.33 \%$ dan dari 12 anak yang telah tuntas

sebanyak 11 anak, dan 1 orang anak belum mencapai ketuntasan belajar. Tetapi secara klasikal ketuntasan belajar yang telah tercapai sebesar $91.67 \%$ ( termasuk 
kategori tuntas ). Hasil pada siklus III ini mengalami peningkatan lebih baik dari siklus II. Adanya peningkatan hasil belajar pada siklus III ini dipengaruhi oleh adanya peningkatan kemampuan guru dalam menerapkan strategi kontekstual, sehingga anak menjadi lebih terbiasa dengan pembelajaran seperti ini sehingga anak lebih mudah dalam memahami materi yang telah diberikan. Di samping itu ketuntasan ini juga dipengaruhi oleh kerja sama dari anak yang telah menguasai materi pelajaran untuk mengajari temannya yang belum menguasai.

c) Refleksi

Pada tahap ini dikaji apa yang telah terlaksana dengan baik maupun yang masih kurang baik dalam proses belajar mengajar dengan penerapan strategi kontekstual. Dari data-data yang telah diperoleh dapat duraikan sebagai berikut: (1) Selama proses belajar mengajar guru telah melaksanakan semua pembelajaran dengan baik. Meskipun ada beberapa aspek yang belum sempurna, tetapi persentase pelaksanaannya untuk masing-masing aspek cukup besar. (2) Berdasarkan data hasil pengamatan diketahui bahwa anak aktif selama proses belajar berlangsung. (3) Kekurangan pada siklus-siklus sebelumnya sudah mengalami perbaikan dan peningkatan sehingga menjadi lebih baik. (4) Kemampuan anak mengucapkan suku kata pada siklus III mencapai ketuntasan.

d) Revisi Pelaksanaan

$$
\text { Pada siklus III guru telah }
$$
menerapkan strategi kontekstual dilaksanakan dengan baik dan dilihat dari aktivitas anak serta hasil belajar anak pelaksanaan proses belajar mengajar sudah berjalan dengan baik. Maka tidak diperlukan revisi terlalu banyak, tetapi yang perlu diperhatikan untuk tindakah selanjutnya adalah memaksimalkan dan mempertahankan apa yang telah ada dengan tujuan agar pada pelaksanaan proses belajar mengajar selanjutnya penerapan strategi kontekstual dapat meningkatkan proses belajar mengajar sehingga tujuan pembelajaran dapat tercapai.

\section{Analisis Hasil Kegiatan}

Setelah dilakukan tindakan pada siklus 1 , siklus 2 dan siklus 3 menunjukkan hasil sebagai berikut:

Tabel 4. Analisis Hasil Tes Tentang Peningkatan Kemampuan Anak Dalam Mengucapkan Suka Kata Sebelum dan Sesudah diberi Tindakan.

\begin{tabular}{|c|c|c|c|c|}
\hline No & Nama Anak & $\begin{array}{l}\text { Skor } \\
\text { sebelum } \\
\text { Tindakan } \\
\text { Siklus 1 } \\
\end{array}$ & $\begin{array}{l}\text { Skor } \\
\text { setelah } \\
\text { Tindakan 1 } \\
\text { Siklus 2 }\end{array}$ & $\begin{array}{l}\text { Skor setelah } \\
\text { Tindakan } 2 \\
\text { Siklus } 3\end{array}$ \\
\hline 1 & Alfi & 65 & 75 & 75 \\
\hline 2 & Balqis & 65 & 75 & 75 \\
\hline 3 & Bintang & 65 & 70 & 75 \\
\hline 4 & Candra & 65 & 75 & 75 \\
\hline 5 & Rissa & 65 & 75 & 75 \\
\hline 6 & Faiza & 60 & 65 & 70 \\
\hline 7 & Nayla & 60 & 65 & 80 \\
\hline 8 & Friska & 75 & 75 & 85 \\
\hline 9 & Obi & 75 & 75 & 85 \\
\hline 10 & Najwa & 70 & 62 & 75 \\
\hline 11 & Alfis & 75 & 75 & 85 \\
\hline 12 & Robbi & 75 & 75 & 85 \\
\hline \multicolumn{2}{|c|}{ Jumlah Total } & 815 & 862 & 940 \\
\hline \multirow{2}{*}{\multicolumn{2}{|c|}{$\begin{array}{l}\text { Skor Maksimum Individu } \\
\text { Skor Maksimum Kelas }\end{array}$}} & 100 & 100 & 100 \\
\hline & & 1200 & 1200 & 1200 \\
\hline
\end{tabular}

\section{Analisis Data Deskriptif Kuantitatif}

1. Pencapaian kemampuan anak mengucapkan suku kata melalui penerapan strategi kontekstual sebelum diberi tindakan
2. Pencapaian peningkatan kemampuan anak mengucapkan suku kata dalam mengucapkan suku kata setelah diberi tindakan pengelompokan anak 
berdasarkan nomor panggilan (acak berdasarkan tempat duduk )

$$
=\underline{862} \times \begin{gathered}
100 \%=71.83 \% \\
1200
\end{gathered}
$$

3. Pencapaian peningkatan kemampuan anak mengucapkan suku kata setelah diberi tindakan pengelompokan anak berdasarkan kemampuan akademik

$$
=\underline{940} \times 100 \%=78.33 \% \text {. }
$$$$
1200
$$

Dari hasil analisis tersebut dapat disimpulkan bahwa:

A. Terjadi peningkatan prestasi setelah diberi tindakan yaitu terjadi $71.83 \%$ menjadi $78.33 \%$ ada kenaikan sebesar $=6.5 \%$

B. Dari sebelum tindakan ( siklus 1 ) dan setelah tindakan sampai dengan ( siklus 3 ) $67.92 \%$ menjadi $78.33 \%$, dan dari ( siklus 2 ) ke ( siklus 3 ) juga ada peningkatan sebanyak 78.33 $\%-71.83 \%=6.5 \%$.

C. Rata - rata anak sebelum diberi tindakan naik $7,16 \%$ menjadi $78.33 \%$.

D. Dari tindakan siklus 2 dan setelah tindakan ( siklus 3 ) $71.83 \%$ menjadi $78.33 \%$ berarti ada peningkatan prestasi sebanyak $78.33 \%-71.83 \%=$ $6,5 \%$.

\section{Refleksi dan Temuan}

Berdasarkan pelaksanaan tindakan maka hasil observasi nilai, hasil dapat dikatakan sebagai berikut:

a. Pertemuan pertama kegiatan belajarmengajar dengan menggunakan strategi kontekstual belum berhasil karena dalam pembelajaran masih terlihat anak yang bermain, bercerita, dan mengganggu anak lain;

b. Model pembelajaran melalui penerapan strategi kontekstual, dalam hal peningkatan kemampuan anak mengucapkan suku kata belum tampak, sehingga hasil yang dicapai tidak tuntas.

c. Mungkin karena proses belajar mengajar yang dilakukan dengan model pembelajaran melalui penerapan strategi kontekstual yang baru mereka laksanakan sehingga anak merasa kaku dalam menerapkannya.

d. Akan tetapi setelah dijelaskan, mereka bisa mengerti dan buktinya pada pertemuan kedua dan ketiga proses kegiatan belajar - mengajar berjalan baik, semua anak aktif dan lebih-lebih setelah ada rubrik penilaian proses, seluruh anak langsung aktif belajar.

\section{Pembahasan Hasil Penelitian}

1. Ketuntasan belajar anak;

Berdasarkan hasil penelitian ini menunjukkan bahwa penerapan strategi kontekstual memiliki dampak positif dalam meningkatkan kemampuan anak mengucapkan suku kata, hal ini dapat dilihat dari semakin mantapnya pemahaman anak terhadap materi yang disampaikan guru ( ketuntasan belajar meningkat dari siklus I, II, dan III ) yaitu masing-masing $67.92 \% ; 71.83 \% ; 78.33$ $\%$ Pada siklus III ketuntasan belajar anak secara klasikal telah tercapai.

2. Kemampuan guru dalam mengelola pembelajaran;

Berdasarkan analisis data, diperoleh aktivitas anak dalam proses pembelajaran melalui penerapan strategi kontekstual dalam setiap siklus mengalami peningkatan. Hal ini berdampak positif terhadap kemampuan anak mengucapkan suku kata yaitu dapat ditunjukkan dengan meningkatnya nilai rata-rata anak pada setiap siklus yang terus mengalami peningkatan.

3. Aktivitas guru dan anak dalam pembelajaran;

Berdasarkan analisis data, diperoleh aktivitas anak dalam proses pembelajaran di taman kanak-kanak dengan menerapkan strategi kontekstual yang paling dominan adalah bekerja dengan menggunakan alat/media, mendengarkan/memperhatikan penjelasan guru, dan diskusi antar anak /antara anak dengan guru. Jadi dapat dikatakan bahwa aktivitas anak dapat dikategorikan aktif. Sedangkan untuk aktivitas guru selama pembelajaran telah melaksanakan langkah-langkah 
pembelajaran melalui penerapan strategi kontekstual dengan baik. Hal ini terlihat dari aktivitas guru yang muncul di antaranya aktivitas membimbing dan mengamati anak dalam mengerjakan kegiatan pembelajaran, menjelaskan, memberi umpan balik/evaluasi/tanya jawab di mana prosentase untuk aktivitas di atas cukup besar.

Berdasarkan hasil penelitian di atas, maka kemampuan anak mengucapkan suku kata di Taman Kanak-Kanak dengan menggunakan strategi kontekstual hasilnya sangat baik. Hal itu tampak pada pertemuan pertama dari 12 orang anak yang hadir pada saat penelitian ini dilakukan nilai rata rata mencapai ; 67.92 \% meningkat menjadi $71.83 \%$ dan pada siklus 3 meningkat menjadi $78.33 \%$. Dari analisis data di atas bahwa pembelajaran dengan strategi kontekstual, yang berarti proses kegiatan belajar mengajar lebih berhasil dan dapat meningkatkan kemampuan anak mengucapkan suku kata khususnya pada anak di TK Bunga Harapan Kec. Babat, oleh karena itu diharapkan kepada para guru TK dapat melaksanakan pembelajaran dengan menggunakan strategi kontekstual.

Berdasarkan kerikulum tingkat satuan pendidikan ( KTSP ) anak dikatakan tuntas apabila anak telah mencapai nilai standar ideal 75 mencapai $\geq$ $85 \%$. Sedangkan pada penilitian ini, pencapai nilai $\geq 75$ pada ( siklus 3 ) mencapai melebihi target yang ditetapkan dalam KTSP yaitu mencapai $91.67 \%$. Dengan demikian maka hipotesis yang diajukan dapat diterima.

\section{KESIMPULAN}

Dari hasil kegiatan pembelajaran yang telah dilakukan selama tiga siklus, dan berdasarkan seluruh pembahasan serta analisis yang telah dilakukan dapat disimpulkan sebagai berikut: (1) Pembelajaran dengan menggunakan strategi kontekstual memiliki dampak positif dalam meningkatkan kemampuan anak mengucapkan suku kata di TK Bunga Harapan Kec. Babat yang ditandai dengan peningkatan ketuntasan belajar anak dalam setiap siklus, yaitu siklus I ( $67.92 \%)$, siklus II ( $71.83 \%$ ), dan siklus III ( 78.33 $\%$ ). (2) Penggunaan strategi kontekstual mempunyai pengaruh positif, yaitu dapat meningkatkan kemampuan anak mengucapkan suku kata. (3) Penerapan strategi kontekstual efektif untuk meningkatkan kembali materi ajar yang telah diterima anak selama ini, sehingga mereka merasa siap untuk menghadapi pelajaran berikutnya.

\section{DAFTAR PUSTAKA}

Anonim, 1993. Kamus Besar Bahasa Indonesia. Jakarta : Balai Pustaka, Edisi Kedua, Cetakan Pertama.

Arikunto,Suharsimi.2007.Penelitian

Tindakan Kelas.Jakarta :

PT.Bumi Aksara

Depdiknas RI,2004.Undang Undang No 20 tentang sistem pendidikan nasional (SISDIKNAS) Jakarta : Depdiknas. 2006.Pedoman pembelajaran bidang pengembangan Pembiasaan TK.Jakarta : Dirjen Dikdasmen.

Harjasujana,Slmet,Ahmat,1997.Membaca 2 Jakarta : Dikdasmen.

Martono.Harlina.Lydia.2006.Pencegahan dan penanggulangan penyalahgunaan narkotika berbasis sekolah.Jakarta : PT Balai Pustaka.

Somantri,Susanyi,Annie.2001 Metode Pengembangan Kemampuan Berbahasa.Jakarta : Dirjen Dikdasmen Pusat Pengembangan Penataran Guru Tertulis.

Sadiman, Arief. Dkk 2007. Media Pendidikan: Pengertian, Pengembangan, dan Pemanfaatannya. Jakarta : PT. Raja Grafindo Persada. 